\title{
Antioxidative effect of Lactobacillus plantarum Y44 on 2,2'-azobis(2-methylpropionamidine) dihydrochloride (ABAP)-damaged Caco-2 cells
}

\author{
Guangqing Mu, ${ }^{1,2}$ Huanyu $\mathrm{Li}^{1}{ }^{1}$ Yanfeng Tuo, ${ }^{1,2 *}$ Yuan Gao, ${ }^{1,2}$ and Yuqing Zhang ${ }^{1}$ \\ ${ }^{1}$ School of Food Science and Technology, Dalian Polytechnic University, Dalian 116034, P. R. China \\ ${ }^{2}$ Dalian Probiotics Function Research Key Laboratory, Dalian Polytechnic University, Dalian 116034, P. R. China
}

\section{ABSTRACT}

Some Lactobacillus strains have been reported to have antioxidative activity. In our previous work, we screened Lactobacillus plantarum Y44 for its antioxidative activity. In this study, we further studied the antioxidative activities of L. plantarum Y44 using chemical antioxidant methods, including the 2,2-diphenyl-1-picrylhydrazyl and 2,2'-azino-bis(3-ethylbenzothiazoline6 -sulfonic acid) free radical scavenging assays, the ferric reducing antioxidant power test, and oxygen radical absorbance capacity test, and we assessed damage caused by 2,2'-azobis(2-methylpropionamidine) dihydrochloride (ABAP) in a Caco-2 cell model. The results of the chemical antioxidant assays confirmed the antioxidative activity of L. plantarum Y44, which was consistent with the protection of Caco-2 cells against ABAP injury by L. plantarum Y44. We also found that L. plantarum Y44 significantly promoted expression of Nrf2 pathway-associated proteins, downregulated expression of inflammatory-related cytokines IL-8 and tumor necrosis factor- $\alpha$ in ABAP-damaged Caco-2 cells, and enhanced expression of the tight junction proteins $\beta$-catenin and E-cadherin. We determined that L. plantarum Y44 exerted antioxidative effects by quenching oxygen free radicals and activating the Nrf2 signaling pathway in Caco-2 cells.

Key words: Lactobacillus plantarum Y44, antioxidative activity, Nrf2 signaling pathway, anti-inflammatory effect, cell barrier

\section{INTRODUCTION}

Consumption of alcohol, smoking, a high-fat diet, and fatigue can result in oxidative stress in humans

Received February 7, 2019.

Accepted April 5, 2019.

*Corresponding author: tuoyf@dlpu.edu.cn due to the presence of excessive reactive oxygen species (ROS) in the body. Oxidative stress mediated by ROS is related to the development of chronic diseases, including aging, inflammation, cancer, atherosclerosis, and cardiovascular disease (Mishra et al., 2015). The human body can scavenge ROS via antioxidant enzymes such as superoxide dismutase (SOD), catalase (CAT), and glutathione peroxidase (GPX-1) in cells. However, when the ROS content in the body exceeds the amount that can be removed by normal metabolism, function and health are adversely affected. Consuming antioxidants can help to scavenge ROS (Reuter et al., 2010).

In vitro and in vivo studies have shown that probiotics exhibit antioxidant potential and consumption of probiotics may reduce oxidative damage (Mishra et al., 2015). Many studies have shown that different probiotic strains, commonly Lactobacillus strains, can exert antioxidant effects, primarily through metal ion chelation, antioxidant enzyme system, free radical scavenging, probiotic-mediated antioxidant signaling pathways, and regulation of intestinal microbiota (Wang et al., 2017).

Some lactobacilli exert antioxidant activity by regulating the signaling pathway associated with oxidative stress in the host, such as nuclear factor-erythroid 2-related factor-2-antioxidant response element (Nrf2/ ARE), a key endogenous pathway regulating the transcriptional expression of various antioxidant enzymes. Furumoto et al. (2016) found that 10-oxo-trans11-octadecenoic acid produced by L. plantarum could protect HegG2 cells against hydrogen peroxide damage by activating the Nrf2 pathway and enhancing the expression of antioxidant genes of HepG2 cells. In vivo studies have shown that the ingestion of L. plantarum CAI6 and L. plantarum SC4 (Wang et al., 2013), L. plantarum C88 (Huang et al., 2017), and L. plantarum AR501 (Lin et al., 2018) significantly increased expression of the Nrf2 gene and upregulated expression of several antioxidant enzymes in mice with symptoms associated with high oxidative stress.

Oxidative stress induced by ROS is a leading cause of inflammatory bowel disease and chronic intestinal 
inflammatory disorders (Witaicenis et al., 2014). Excessive ROS can enhance the permeability of intestinal epithelial cells and disrupt their barrier function and integrity (Ma et al., 2004). Consumption of probiotics can alleviate the intestinal inflammation caused by ROS and enhance the barrier function of intestinal epithelial cells (Mishra et al., 2015). Anderson et al. (2010) showed that L. plantarum MB452 improves intestinal barrier function by enhancing the expression of genes involved in tight junction signaling. Finamore et al. (2018) showed that Lactobacillus casei Shirota could prevent membrane barrier disruption and ROS accumulation inside enterocytes through the Nrf2 pathway.

In our previous work (Mu et al., 2018), L. plantarum Y44 was screened as a potential probiotic strain with antioxidative activities shown by scavenging ROS and protecting the human colon cancer cell line HT-29 against $\mathrm{H}_{2} \mathrm{O}_{2}$ injury.

In this study, we used chemical antioxidative methods and a cellular antioxidant assay (CAA) to assess the ROS quenching ability of L. plantarum Y44. To explain the mechanisms by which L. plantarum Y44 exerts antioxidative activity, we then determined the effect of L. plantarum Y44 on expression of tight junction proteins, inflammatory-related cytokines, and Nrf2 pathway-associated proteins in Caco-2 cells that were injured using 2,2'-azobis(2-methylpropionamidine) dihydrochloride (ABAP).

\section{MATERIALS AND METHODS}

\section{Bacterial Strains and Culture Conditions}

Lactobacillus plantarum Y44 tested in this study was isolated from traditional fermented food in Liaoning Province (China) and stored in de Man, Rogosa, and Sharpe (MRS) medium (AOBOX Biotechnology, Qingdao, China) containing $25 \%$ glycerol at $-80^{\circ} \mathrm{C}$. Lactobacillus plantarum Y44 was inoculated in $5 \mathrm{~mL}$ of sterile MRS broth and incubated at $37^{\circ} \mathrm{C}$ for $18 \mathrm{~h}$. After 3 successive cultures in MRS broth at $37^{\circ} \mathrm{C}$ for $18 \mathrm{~h}$, the bacterial cells were collected by centrifugation at $3,214 \times g$ for $10 \mathrm{~min}$ at $4^{\circ} \mathrm{C}$ (Eppendorf, Hamburg, Germany) and the cells washed twice with sterile PBS (pH 7.4, Gibco Life Technologies, Grand Island, NY).

\section{Cell Culture}

Caco-2 human colon cancer cells were obtained from the Cell Bank of the Chinese Academy of Sciences (CBCAS, Shanghai, China), and cultured in Dulbecco's modified Eagle medium (DMEM; Hyclone, Logan, UT) supplemented with $20 \%$ fetal bovine serum (Bio- logical Industries, Beit Haemek, Israel), penicillin (100 $\mathrm{U} / \mathrm{mL}$ ), and streptomycin (100 U/mL; Sigma-Aldrich, St. Louis, MO) at $37^{\circ} \mathrm{C}$ in an incubator with $90 \%$ humidity and $5 \% \mathrm{CO}_{2}$. The culture medium was replaced every $48 \mathrm{~h}$ to maintain the cells.

\section{2,2-Diphenyl-1-Picrylhydrazyl Radical Scavenging Assay}

The 2,2-diphenyl-1-picrylhydrazyl (DPPH) radical scavenging assay was used to evaluate free radical scavenging activity of L. plantarum Y44 and was performed as described in Chen et al. (2014) with minor modifications. First, L. plantarum Y44 were subcultured in MRS broth at $37^{\circ} \mathrm{C}$ for $18 \mathrm{~h}$ twice before use. Intact cells of L. plantarum $\mathrm{Y} 44$ were harvested by centrifugation at $2,057 \times g$ for $10 \mathrm{~min}$ at $4^{\circ} \mathrm{C}$ (Eppendorf). The cell pellets were washed twice with PBS (pH 7.4, Gibco Life Technologies) and resuspended in PBS, adjusting the cell concentrations to $10^{7}, 10^{8}, 10^{9}$, and $10^{10} \mathrm{cfu} / \mathrm{mL}$. One milliliter of each L. plantarum Y44 concentration was added to $1.0 \mathrm{~mL}$ of DPPH-ethanol solution (0.02 $\mathrm{m} M$; Sigma-Aldrich). The mixtures were incubated at $25^{\circ} \mathrm{C}$ in the dark for $30 \mathrm{~min}$. The control included PBS and DPPH-ethanol solution without L. plantarum. The blank contained L. plantarum Y44 suspensions at different concentrations and ethanol. After incubation, the mixture was centrifuged at $1,575 \times g$ for $10 \mathrm{~min}$, and the optical absorbance of the supernatant at $517 \mathrm{~nm}$ was measured in triplicate by using a Multiskan GO microplate reader (Thermo Fisher Scientific, Waltham, MA). The DPPH radical scavenging ability was calculated using the following equation:

$$
\begin{gathered}
\text { Scavenging activity }(\%)= \\
{\left[1-\left(\mathrm{A}_{\text {sample }}-\mathrm{A}_{\text {blank }}\right) / \mathrm{A}_{\text {control }}\right] \times 100 \%,}
\end{gathered}
$$

where $A_{\text {sample }}, A_{\text {blank }}$, and $A_{\text {control }}$ represent the optical absorbance at $517 \mathrm{~nm}$ of the sample, blank, and control, respectively. All samples were analyzed in triplicate.

\section{2,2'-Azino-bis (3-ethylbenzothiazoline-6-sulfonic acid) Radical Scavenging Assay}

A previously described method for the 2,2'-azino-bis (3-ethylbenzothiazoline-6-sulfonic acid) (ABTS) assay was used with slight modifications (Li et al., 2015). The stock solution, which was allowed to stand in the dark for $16 \mathrm{~h}$ at room temperature, contained equal volumes of $7 \mathrm{mmol} / \mathrm{L}$ ABTS salt (Sigma-Aldrich) and 2.5 $\mathrm{mmol} / \mathrm{L}$ potassium persulfate (Sigma-Aldrich). Then, the resultant $\mathrm{ABTS}^{+}$solution was diluted with $0.02 \mathrm{M}$ 
PBS (pH 7.4) until an absorbance of $0.70 \pm 0.01$ at 734 $\mathrm{nm}$ was obtained. Then, $0.4 \mathrm{~mL}$ of each sample at various concentrations $\left(10^{7}, 10^{8}, 10^{9}\right.$, and $\left.10^{10} \mathrm{cfu} / \mathrm{mL}\right)$ of L. plantarum $\mathrm{Y} 44$ was added to $3 \mathrm{~mL}$ of diluted ABTS solution. The mixture was shaken vigorously for $30 \mathrm{~s}$, left in the dark for $6 \mathrm{~min}$, and then centrifuged at 2,057 $\times g$ for $5 \mathrm{~min}$ at room temperature. The absorbance of the resulting supernatant was measured at $734 \mathrm{~nm}$ using a UV-visible spectrophotometer (Thermo Fisher Scientific). An equivalent volume of distilled water instead of sample was used for the control. The ability to scavenge the $\mathrm{ABTS}^{\bullet+}$ was calculated using the following equation:

$$
\begin{aligned}
& \operatorname{ABTS}^{\bullet+} \text { scavenging activity }(\%)= \\
& {\left[\left(\mathrm{A}_{\text {control }}-\mathrm{A}_{\text {sample }}\right) / \mathrm{A}_{\text {control }}\right] \times 100 \%,}
\end{aligned}
$$

where $\mathrm{A}_{\text {control }}$ and $\mathrm{A}_{\text {sample }}$ are the absorbance at $734 \mathrm{~nm}$ of the control and sample, respectively. All samples were analyzed in triplicate.

\section{Ferric Reducing Antioxidant Power Assay}

To measure reducing power, the ferric reducing antioxidant power (FRAP) assay was carried out as previously described (Stinco et al., 2015) with slight modifications. The FRAP reagent contained $100 \mathrm{~mL}$ of $0.3 \mathrm{M}$ acetate buffer, $\mathrm{pH} 3.6,10 \mathrm{~mL}$ of $10 \mathrm{mM}$ 2,4,6-tris(2-pyridyl)-s-triazine (TPTZ; Sigma-Aldrich) in $40 \mathrm{mM} \mathrm{HCl}$ (Sigma-Aldrich) and $10 \mathrm{~mL}$ of 20 $\mathrm{mmol} / \mathrm{L} \mathrm{FeCl}_{3} \cdot 6 \mathrm{H}_{2} \mathrm{O}$ (Sigma-Aldrich) and was freshly prepared before use. The FRAP assay is based on the ability of antioxidant substances to reduce $\mathrm{Fe}^{3+}$-TPTZ to $\mathrm{Fe}^{2+}$-TPTZ. Briefly, $100 \mu \mathrm{L}$ of L. plantarum Y44 dilutions at different concentrations was added to $3 \mathrm{~mL}$ of FRAP reagent, the mixture was incubated at room temperature for $6 \mathrm{~min}$ in the dark, and the absorbance was measured at $593 \mathrm{~nm}$; the FRAP reagent alone was used as a control. Ascorbic acid was tested as a standard antioxidant compound.

\section{Oxygen Radical Absorbance Capacity Assay}

The oxygen radical absorbance capacity (ORAC) assay is a widely used method to analyze total antioxidants. The ORAC assay was evaluated as described by Persichetti et al. (2014), with some modifications. Briefly, $20 \mu \mathrm{L}$ of sample $\left(10^{7}, 10^{8}, 10^{9}\right.$, and $10^{10} \mathrm{cfu} /$ $\mathrm{mL}$ of L. plantarum Y44 dissolved in PBS) was added into the wells of black, clear-bottomed 96-well plates (Corning Inc., Corning, NY), and $20 \mu \mathrm{L}$ of fluorescein (Sigma-Aldrich) was added at a final concentration of
$0.96 \mu M$. The mixture was automatically shaken and incubated for $20 \mathrm{~min}$ at $37^{\circ} \mathrm{C}$. Then, $140 \mu \mathrm{L}$ of 12.8 $\mathrm{m} M$ 2,2'-azobis(2-methylpropionamidine) dihydrochloride (ABAP, Sigma-Aldrich) was added to each well. The fluorescence intensity was measured and recorded using a SpectraMax M2 microplate reader (Molecular Devices, Sunnyvale, CA) at excitation and emission wavelengths of 485 and $538 \mathrm{~nm}$ for 41 cycles every 4.5 min. Trolox was used as the positive control. The ORAC values for lactobacilli strains were expressed as Trolox equivalents (TE) with the same antioxidant activity $(\mathrm{m} M)$ in triplicates.

\section{Cell Cytotoxicity Assay}

Cytotoxicity of the lactobacilli strains was measured using a modified methylene blue assay (Xing et al., 2015a). Briefly, Caco-2 cells were seeded at a density of $4 \times 10^{5}$ cells $/ \mathrm{mL}$ in a 96 -well microplate (Corning Inc.) in $100 \mu \mathrm{L}$ of DMEM for $24 \mathrm{~h}$ at $37^{\circ} \mathrm{C}$. After washing with PBS (pH 7.4) twice, the cells were treated with $100 \mu \mathrm{L}$ of sample $\left(10^{7}, 10^{8}, 10^{9}\right.$, or $10^{10} \mathrm{cfu} / \mathrm{mL}$ of $L$. plantarum Y44 suspended in DMEM) or DMEM alone (control group) for up to $24 \mathrm{~h}$ at $37^{\circ} \mathrm{C}$. To assess cell viability, cells were washed with $\mathrm{PBS}$ twice and then incubated with methylene blue (98\% Hanks' Balanced Salt Solution, HBSS; $0.67 \%$ glutaraldehyde; and $0.6 \%$ methylene blue) at $50 \mu \mathrm{L} /$ well for $1 \mathrm{~h}$ at $37^{\circ} \mathrm{C}$. After incubation, the cells were washed with deionized water 6 times until the water was clear, and $100 \mu \mathrm{L} /$ well of elution solution (49\% PBS, $50 \%$ ethanol, and $1 \%$ acetic acid) was added. Then, the microplate was shaken on a microplate oscillator (IKA, Wilmington, DE) for $20 \mathrm{~min}$ and absorbance was measured at $570 \mathrm{~nm}$. Different samples were compared with the control. The sample was considered cytotoxic when the absorbance decreased by $>10 \%$ compared with the control.

\section{CAA of Lactobacilli Strains}

Cellular antioxidant assays of Lactobacillus strains were conducted according to the method of Xing et al. (2015b), with some modifications. The Caco-2 cells were seeded at a density of $6 \times 10^{4}$ cells/well in black, clear-bottomed 96-well plates (Corning Inc.) in $100 \mu \mathrm{L}$ of DMEM and incubated for $24 \mathrm{~h}$ at $37^{\circ} \mathrm{C}$ to reach $80 \%$ confluence. The cells were treated with $100 \mu \mathrm{L}$ of sample $\left(10^{7}, 10^{8}, 10^{9}\right.$, or $10^{10} \mathrm{cfu} / \mathrm{mL}$ of $L$. plantarum Y44 suspended in DMEM) after being washed twice with PBS including $25 \mu M 2^{\prime}, 7^{\prime}$-dichlorofluorescein diacetate (DCFH-DA, Sigma-Aldrich) for up to $1 \mathrm{~h}$ at $37^{\circ} \mathrm{C}$. Final concentrations of $1,2,4,8,16$, and 32 
$\mu M$ quercetin was used to make a standard curve according to Wolfe et al. (2007). Subsequently, cells were washed with PBS twice and treated with $100 \mu \mathrm{L}$ of 600 $\mu M$ ABAP (dissolved in HBSS). Fluorescence was measured by using the SpectraMax M2 microplate reader (Molecular Devices) for 13 cycles at 5-min intervals (excitation and emission wavelengths of 485 and 538 $\mathrm{nm})$. The area under the curve of fluorescence versus time was integrated to calculate the CAA value of each sample after a blank subtraction from the fluorescent readings:

$$
\text { CAA value }(\text { units })=\left[1-\left(\int_{\mathrm{SA}} / \int_{\mathrm{CA}}\right)\right] \times 100,
$$

where $\int_{\mathrm{SA}}$ is the integrated area of the sample and $\int_{\mathrm{CA}}$ is the integrated area of the control curve. Cells treated with DCFH-DA were used as blanks, and cells treated with DCFH-DA and ABAP were used as controls. Quercetin was used in each experiment as a standard, and the CAA values (units) for lactobacilli strains were expressed as equivalent amounts of quercetin with the same antioxidant activity $(\mathrm{m} M)$.

\section{ABAP-Damaged Caco-2 Cell Model}

We established an ABAP-damaged Caco-2 cell model according to the method of Yokozawa et al. (2000), with some modifications. Briefly, Caco-2 cells were seeded at a density of $2 \times 10^{5}$ cells $/ \mathrm{mL}$ in a 96-well microplate (Corning Inc.) in $100 \mu \mathrm{L}$ of DMEM and incubated for $24 \mathrm{~h}$ at $37^{\circ} \mathrm{C}$ until attached completely. The cells were treated with $100 \mu \mathrm{L}$ of ABAP (at final concentrations of $70,80,90,100,110,120,130,140$, and $150 \mathrm{mmol} / \mathrm{L}$ in DMEM) or DMEM with $0 \mathrm{mmol} / \mathrm{L} \mathrm{ABAP}$ as control for up to $2 \mathrm{~h}$ at $37^{\circ} \mathrm{C}$. A modified methylene blue assay was used to assess cell viability. The viability of Caco-2 cells was measured at $570 \mathrm{~nm}$ using Multiskan GO microplate reader (Thermo Fisher Scientific) and calculated using the following equation:

$$
\begin{gathered}
\text { Viability }(\%)= \\
{\left[\left(\mathrm{A}_{\text {sample }}-\mathrm{A}_{\text {blank }}\right) /\left(\mathrm{A}_{\text {control }}-\mathrm{A}_{\text {blank }}\right)\right] / \mathrm{A}_{\text {control }} \times 100,}
\end{gathered}
$$

where $\mathrm{A}_{\text {control }}, \mathrm{A}_{\text {sample }}$, and $\mathrm{A}_{\text {blank }}$ represent the optical absorbance at $570 \mathrm{~nm}$ of the control, sample, and blank, respectively. All samples were analyzed in triplicate.

According to the viability results, we determined the semi-lethal concentration of ABAP to Caco-2 cells and then assessed the effect of $L$. plantarum Y44 on survival of Caco-2 cells damaged by the semi-lethal concentration of ABAP, according to Elisia and Kitts (2008). The experiment was divided into 3 groups: cells, cells
+ ABAP, cells + ABAP + L. plantarum Y44. Briefly, Caco-2 cells were seeded at a density of $2 \times 10^{5}$ cells/ $\mathrm{mL}$ in a 96 -well microplate (Corning Inc.) in $100 \mu \mathrm{L}$ of DMEM and incubated for $24 \mathrm{~h}$ at $37^{\circ} \mathrm{C}$ until attached completely. After washing with PBS (pH 7.4) twice, the cells were treated with $100 \mu \mathrm{L}$ of sample $\left(10^{9} \mathrm{cfu} / \mathrm{mL}\right.$ of L. plantarum Y44 dissolved in DMEM) or DMEM (cell and cell + ABAP groups) for up to $8 \mathrm{~h}$ at $37^{\circ} \mathrm{C}$. After washing with PBS (pH 7.4) 3 times, the cells were treated with $100 \mu \mathrm{L}$ of ABAP (or with $100 \mu \mathrm{L}$ of DMEM for the cell group) for up to $2 \mathrm{~h}$ at $37^{\circ} \mathrm{C}$. A modified methylene blue assay was used to assess cell viability, which was calculated using the equation above.

\section{Scanning Electron Microscopy}

The Caco-2 cells treated above (in the cells, cells + ABAP, cells + ABAP + L. plantarum Y44 groups) were photographed using a scanning electron microscope according to Briske-Anderson et al. (1997), with some modifications. The Caco-2 cell monolayers were washed with ice-cold PBS 3 times for 5 min each time, fixed in $4 \%$ electron microscopy-grade paraformaldehyde (Sigma-Aldrich) at $4^{\circ} \mathrm{C}$ for $60 \mathrm{~min}$. The cells were washed with pre-cooled distilled water 3 times for 6 min each time and dehydrated in ethanol at different concentrations $(50,70,90$, and $100 \% \mathrm{vol} / \mathrm{vol}$ ) at 5 min per level. Then, the fixed cells was washed using acetonitrile at different concentrations $(50,70,90$, and $100 \% \mathrm{vol} / \mathrm{vol}$ ), followed by vacuum drying and then gold plating. The fixed cells were observed and imaged using environmental scanning electron microscopy (Jeol JSM-6460LV, Tokyo, Japan).

\section{IL-8, IL-10, and TNF-a Assays}

Two-milliliter aliquots of Caco- 2 cells at $1 \times 10^{6}$ cells $/ \mathrm{mL}$ were seeded in 6 -well plates in complete medium and incubated at $37^{\circ} \mathrm{C}$ in $5 \% \mathrm{CO}_{2}$ and $95 \%$ air atmosphere. The growth medium was changed every 2 $\mathrm{d}$ and cells were cultured to complete confluency. After washing with PBS ( $\mathrm{pH} 7.4$ ) twice, the Caco-2 cells were treated with $100 \mu \mathrm{L}$ of sample $\left(10^{9} \mathrm{cfu} / \mathrm{mL}\right.$ of $L$. plantarum Y44 suspended in DMEM) or DMEM alone (cell and cell + ABAP groups) for up to $8 \mathrm{~h}$ at $37^{\circ} \mathrm{C}$. After washing with PBS (pH 7.4) 3 times, the cells were treated with $100 \mu \mathrm{L}$ of ABAP at the semi-lethal concentration (the cell group was treated with $100 \mu \mathrm{L}$ of DMEM) for up to $2 \mathrm{~h}$ at $37^{\circ} \mathrm{C}$. Finally, the cell culture medium was collected and centrifuged at $3,214 \times$ $g$ to pellet and remove the cells. The detection of IL-8, 
IL-10, TNF- $\alpha$ content in the medium supernatant was carried out using a Human IL-8 ELISA Kit, Human IL-10 ELISA Kit, and Human TNF- $\alpha$ ELISA Kit, respectively (Nanjing Jiancheng Bioengineering Institute; Nanjing, China).

\section{Western Blot Assay}

Western blot analysis was carried out according to $\mathrm{Mu}$ et al. (2018), with some modifications. Twomilliliter aliquots of Caco-2 cells were seeded into 6 -well plates (Corning Inc.) at a density of $1.0 \times 10^{6}$ cells/ $\mathrm{mL}$ and incubated at $37^{\circ} \mathrm{C}$ in $5 \% \mathrm{CO}_{2}$ and $95 \%$ air atmosphere. After $48 \mathrm{~h}$ of cell growth into monolayers, the growth medium was removed and the cells were washed with sterile PBS twice. Cells were pretreated with $2 \mathrm{~mL}$ of sample $\left(10^{9} \mathrm{cfu} / \mathrm{mL}\right.$ of $\mathrm{Y} 44$ suspended in DMEM) for $8 \mathrm{~h}$ and then washed with sterile PBS 3 times. Then, $2 \mathrm{~mL} \mathrm{ABAP}$ at the semi-lethal concentration was added to induce oxidative stress for $2 \mathrm{~h}$. The damage was stopped by removing cultured supernatants, and then the cells were washed with PBS twice and scraped from the wells. The harvested cells were added into radio-immunoprecipitation assay buffer (Solarbio Life Science, Beijing, China) with 1\% phenylmethylsulfonyl fluoride (Solarbio Life Science) and ultrasonically treated for $10 \mathrm{~min}$ to extract protein. Protein concentrations of the lysates were determined using a bicinchoninic acid protein assay kit (Solarbio Life Science). Equal amounts of protein from each cell lysate were subjected to $12 \%$ (wt/vol) SDS-PAGE and transferred to polyvinylidene fluoride membranes. The membranes were blocked for $2 \mathrm{~h}$ with PBS-Tween (PBS containing of $0.05 \%$ Tween 20) containing $5 \%$ nonfat milk at room temperature. Membranes were incubated overnight at $4^{\circ} \mathrm{C}$ with antibodies against Nrf-2, Kelchlike ECH-associated protein 1 (KEAP1), heme oxygenase-1 (HO-1), SOD, CAT, GPX-1 (1:2,000 dilutions in primary antibody dilution buffer, Affinity Biosciences, Cincinnati, OH), $\beta$-catenin, E-cadherin $(1: 2,000$ dilutions in primary antibody dilution buffer, Beyotime Institute of Biotechnology, Shanghai, China), and $\beta$-actin (1:1,000 dilution in primary antibody dilution buffer, Beyotime Institute of Biotechnology), followed by the corresponding horseradish peroxidase-labeled secondary antibodies (all 1:2,000 dilutions in 1\% BSA; Beyotime Institute of Biotechnology) for $1 \mathrm{~h}$ at $4^{\circ} \mathrm{C}$. Protein bands were visualized by using the BeyoECL star kit (Beyotime Institute of Biotechnology) according to the manufacturer's protocol. Bands were then scanned and quantified using ImageJ software (National Institutes of Health, Bethesda, MD). The expression of human $\beta$-actin was used as an internal standard control. All measurements were conducted in triplicate.

\section{Statistics Analysis}

All tests were performed in triplicate. Data are presented as mean \pm standard deviation (SD). One-way ANOVA was performed using SPSS software (version 20.0, SPSS Inc., Chicago, IL) to verify significant differences between samples. The results were considered significant when $P<0.05$.

\section{RESULTS}

\section{Oxygen Free Radical Scavenging Activities of L. plantarum Y44}

We studied the antioxidant activities of L. plantarum Y44 at concentrations from $10^{7}$ to $10^{10} \mathrm{cfu} / \mathrm{mL}$ by using DPPH, ABTS, FRAP, and ORAC assays. As shown in Table 1 , as the concentration of $L$. plantarum Y44 increased, the ROS scavenging capacities of L. plantarum Y44 (as determined by DPPH, ABTS, FRAP, and ORAC assays) gradually increased in a dose-dependent

Table 1. Oxygen free radical scavenging activities ${ }^{1,2}$ of Lactobacillus plantarum Y44

\begin{tabular}{|c|c|c|c|c|}
\hline \multirow{2}{*}{$\begin{array}{l}\text { Concentration of } \\
\text { L. plantarum Y44 }\end{array}$} & \multicolumn{2}{|c|}{$\begin{array}{l}\text { Radical scavenging } \\
\text { activity (\%) }\end{array}$} & \multirow[b]{2}{*}{ FRAP value } & \multirow{2}{*}{$\begin{array}{c}\text { ORAC value } \\
(\mu \mathrm{mol} \text { of } \mathrm{TE} / \mathrm{mL})\end{array}$} \\
\hline & $\mathrm{DPPH}$ & ABTS & & \\
\hline $\begin{array}{l}10^{7} \mathrm{cfu} / \mathrm{mL} \\
10^{8} \mathrm{cfu} / \mathrm{mL} \\
10^{9} \mathrm{cfu} / \mathrm{mL} \\
10^{10} \mathrm{cfu} / \mathrm{mL}\end{array}$ & $\begin{array}{l}12.31 \pm 1.25^{\mathrm{c}} \\
13.97 \pm 1.39^{\mathrm{c}} \\
19.16 \pm 3.19^{\mathrm{b}} \\
60.97 \pm 4.32^{\mathrm{a}}\end{array}$ & $\begin{array}{l}13.99 \pm 1.67^{\mathrm{b}} \\
14.48 \pm 1.67^{\mathrm{b}} \\
16.67 \pm 2.40^{\mathrm{b}} \\
20.48 \pm 2.04^{\mathrm{a}}\end{array}$ & $\begin{array}{r}0.94 \pm 0.08^{\mathrm{c}} \\
1.88 \pm 0.21^{\mathrm{c}} \\
9.20 \pm 0.65^{\mathrm{b}} \\
19.32 \pm 1.80^{\mathrm{a}}\end{array}$ & $\begin{array}{r}6.27 \pm 7.91^{\mathrm{c}} \\
14.60 \pm 5.65^{\mathrm{c}} \\
29.27 \pm 5.70^{\mathrm{b}} \\
76.73 \pm 11.99^{\mathrm{a}}\end{array}$ \\
\hline
\end{tabular}


manner. The results of the 4 assays were consistent with each other.

\section{Cellular Antioxidant Assay}

We further studied the antioxidant profile of L. plantarum Y44 in a quantitative cellular antioxidant assay (CAA) using the human colon cancer Caco-2 cell line to simulate human intestinal tract epithelial cells. As shown in Table 2, L. plantarum Y44 at $10^{10} \mathrm{cfu} / \mathrm{mL}$ reduced the viability of Caco-2 cells to $78.9 \%$, indicating that a bacterial concentration of $10^{10} \mathrm{cfu} / \mathrm{mL}$ was toxic to Caco-2 cells. The survival rates of Caco-2 cells treated with lower concentrations of $L$. plantarum Y44 exceeded $90 \%$ (i.e., were not toxic). The lower $\mathrm{pH}$ of cell culture with L. plantarum Y44 at $10^{10} \mathrm{cfu} / \mathrm{mL}$ might have accounted for the decreased viability of Caco-2 cells.

The L. plantarum Y44 concentrations of $10^{7}, 10^{8}$, and $10^{9} \mathrm{cfu} / \mathrm{mL}$ were selected for additional CAA. As shown in Figure 1b, L. plantarum Y44 at different concentrations reduced DCF fluorescence in a time-dependent manner: fluorescence intensity decreased with increasing L. plantarum Y44 concentration. Thus, L. plantarum Y44 at $10^{9} \mathrm{cfu} / \mathrm{mL}$ had a higher CAA value than the lower concentrations $(P<0.05$; Figure 1a).

\section{Effect of L. plantarum Y44 on Survival Rates of Caco-2 Cells Damaged by ABAP}

We established an ABAP-damage model in this study; ABAP is an oxidant that can damage normal cells. As shown in Figure 2a, the survival rates of Caco2 cells decreased with increased ABAP concentration. A concentration of $130 \mathrm{mmol} / \mathrm{L} \mathrm{ABAP}$ resulted in a survival rate close to $50 \%$; thus, the semi-lethal concentration of ABAP to Caco- 2 cells was $130 \mathrm{mmol} / \mathrm{L}$.

Caco-2 cells were incubated with $L$. plantarum Y44 at $10^{9} \mathrm{cfu} / \mathrm{mL}$ for $8 \mathrm{~h}$ and then $130 \mathrm{mmol} / \mathrm{L}$ ABAP was added to the cultures. The survival rate of the treated

Table 2. Effect of Lactobacillus plantarum Y44 on Caco-2 cell viability and $\mathrm{pH}^{1}$

\begin{tabular}{lrc}
\hline $\begin{array}{l}\text { Concentration of } \\
\text { L. plantarum Y44 }\end{array}$ & $\begin{array}{r}\text { Caco-2 cell } \\
\text { viability }(\%)\end{array}$ & $\mathrm{pH}$ \\
\hline $10^{7} \mathrm{cfu} / \mathrm{mL}$ & $100.54 \pm 4.22^{\mathrm{b}}$ & $7.33 \pm 0.09^{\mathrm{a}}$ \\
$10^{8} \mathrm{cfu} / \mathrm{mL}$ & $99.22 \pm 2.09^{\mathrm{b}}$ & $7.23 \pm 0.07^{\mathrm{a}}$ \\
$10^{9} \mathrm{cfu} / \mathrm{mL}$ & $127.17 \pm 6.14^{\mathrm{a}}$ & $6.86 \pm 0.10^{\mathrm{a}}$ \\
$10^{10} \mathrm{cfu} / \mathrm{mL}$ & $78.99 \pm 4.02^{\mathrm{c}}$ & $5.33 \pm 0.11^{\mathrm{b}}$ \\
\hline
\end{tabular}

${ }^{\mathrm{a}-\mathrm{c}}$ Values within a column with different letters are significantly different at $P<0.05$.

${ }^{1}$ Data are expressed as means $\pm \mathrm{SD}(\mathrm{n}=3)$.
Caco-2 cells was $87.89 \%$, higher $(P<0.05)$ than that of the Caco-2 cells treated only with $130 \mathrm{mmol} / \mathrm{L} \mathrm{ABAP}$ (no preincubation with $L$. plantarum), as shown in Figure 2b, indicating that L. plantarum Y44 protected Caco-2 cells against ABAP oxidative damage. The result was consistent with the CAA value of $L$. plantarum Y44 at $10^{9} \mathrm{cfu} / \mathrm{mL}$.

\section{Effect of L. plantarum Y44 on Cell Integrity of Caco-2 Cells Damaged by ABAP}

The Caco- 2 cells damaged by ABAP were examined by scanning electron microscopy (Figure 3a). Compared

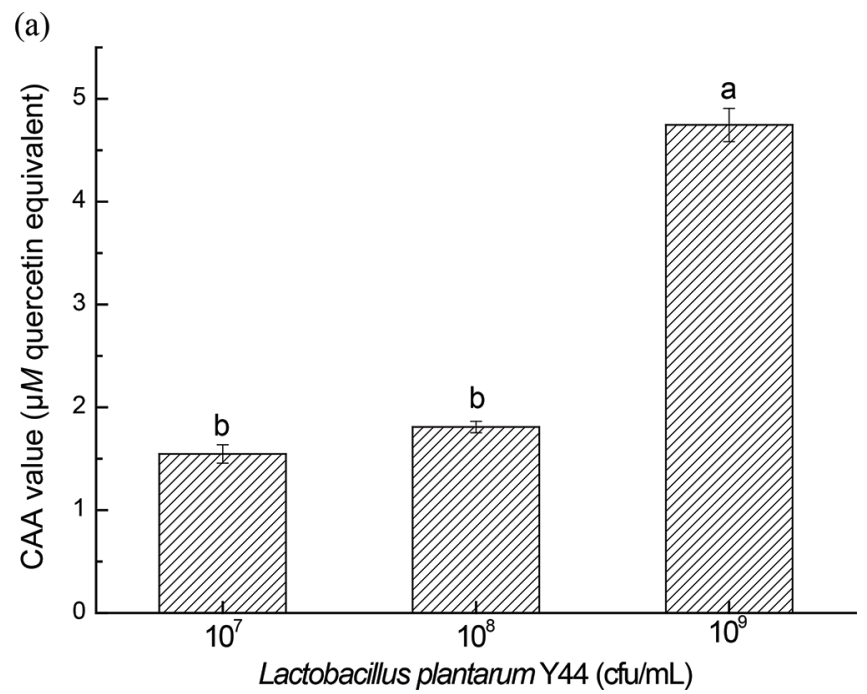

(b)

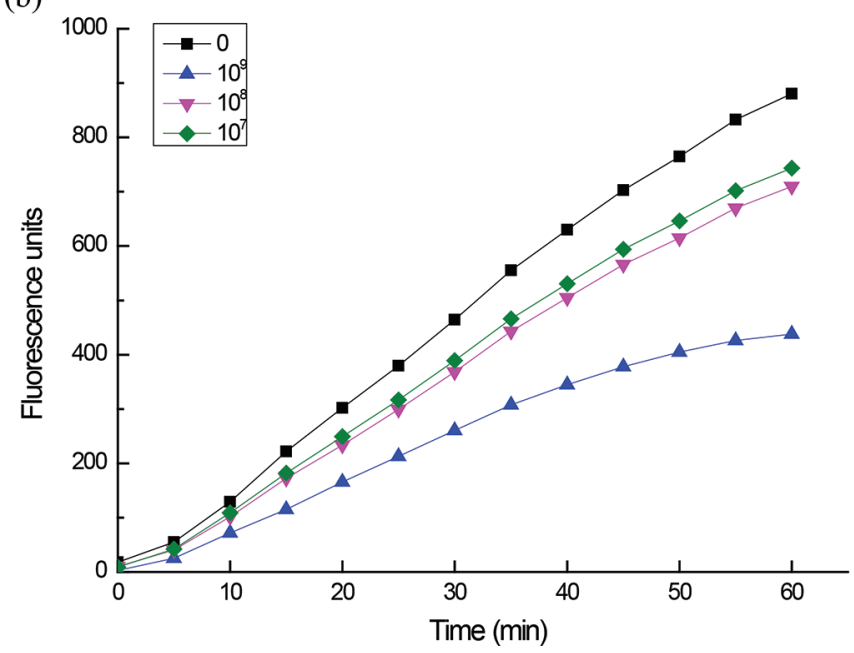

Figure 1. (a) Cellular antioxidant assay (CAA) values of Lactobacillus plantarum Y44; (b) fluorescence units of L. plantarum Y44 at $10^{7}, 10^{8}$, and $10^{9} \mathrm{cfu} / \mathrm{mL}$. Data shown are means $\pm \mathrm{SD}(\mathrm{n}=3)$. Bars with different letters $(\mathrm{a}, \mathrm{b})$ are significantly different $(P<0.05)$. 
with normal cells, the gap between Caco-2 cells treated with ABAP was enlarged, the number of holes in the cell membrane increased, and the tissue structure of the cell membrane was loose and disordered compared with the intact and smooth state of untreated cells. Much less damage to cell integrity was observed when Caco-2 cells were pretreated with L. plantarum Y44 before ABAP.

Cell integrity was related to the expression of tight junction proteins and epithelial barrier function. The expression of 2 tight junction proteins, E-cadherin and
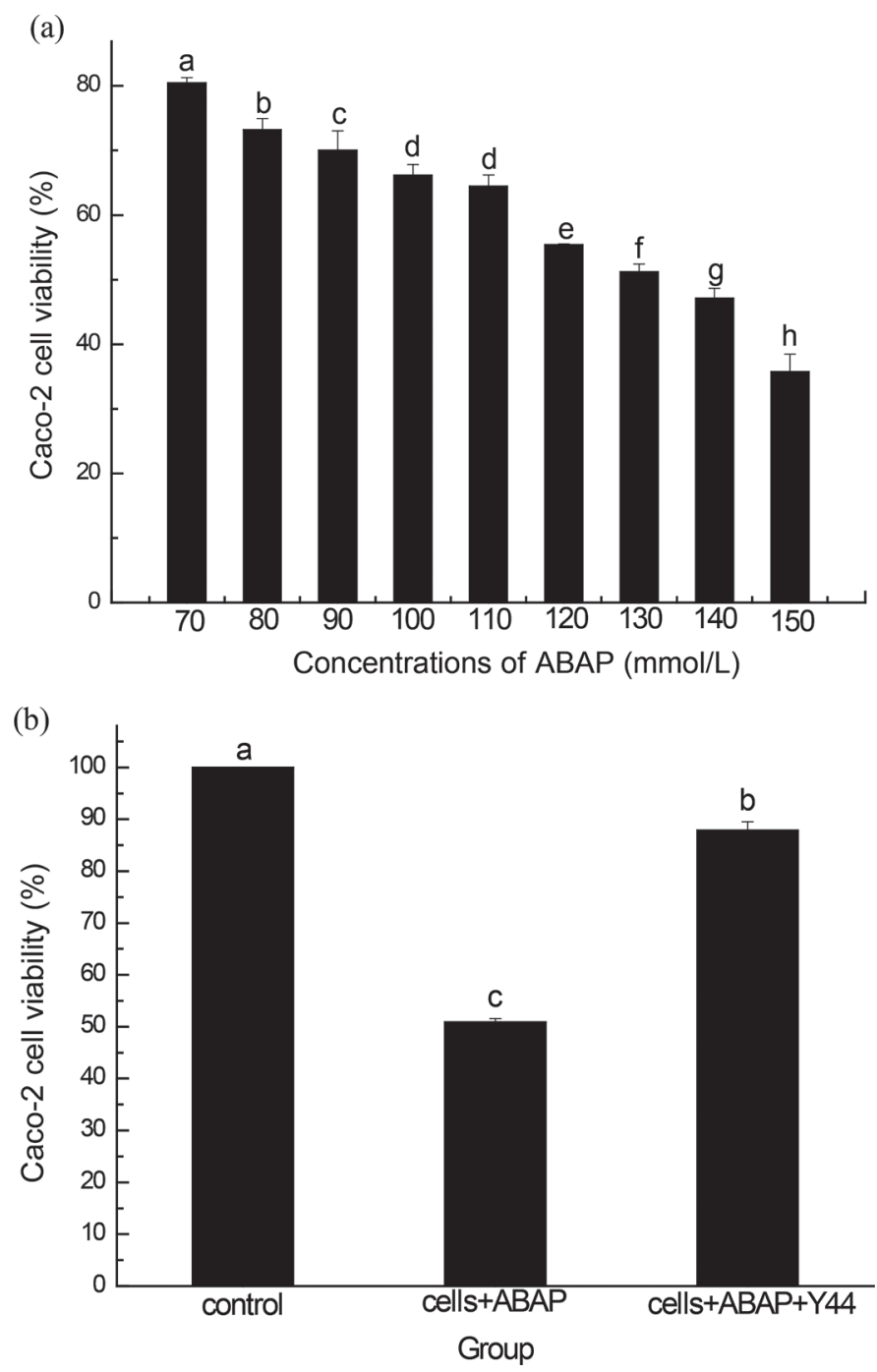

Figure 2. Effect of Lactobacillus plantarum Y44 on the survival rate of 2,2'-azobis(2-methylpropionamidine) dihydrochloride (ABAP)injured Caco-2 cells. (a) Caco-2 cell viability under different concentrations of ABAP; (b) effect of L. plantarum Y44 on the survival rate of ABAP-damaged Caco-2 cells. Data shown are means $\pm \mathrm{SD}(\mathrm{n}=3)$. Bars with different letters $(\mathrm{a}-\mathrm{h})$ are significantly different $(P<0.05)$. $\beta$-catenin, was significantly enhanced $(P<0.05)$ in Caco-2 cells treated with $L$. plantarum Y44 and ABAP compared with Caco-2 cells treated with ABAP alone (Figure 3b-e). The L. plantarum Y44 treatment might have maintained Caco-2 cell integrity by enhancing the expression of E-cadherin and $\beta$-catenin.

\section{Effect of L. plantarum Y44 on Cytokine Expression of Caco-2 Cells Damaged by ABAP}

Excessive oxidation pressure on intestinal epithelial cells induces expression of inflammatory-related cytokines. In this study, expression of IL-8, IL-10, and TNF- $\alpha$ was higher $(P<0.05)$ in ABAP-damaged Caco2 cells than in control Caco-2 cells (Figure 4). Addition of L. plantarum $\mathrm{Y} 44$ resulted in significantly lower $(P<$ 0.05 ) expression of IL- 8 and TNF- $\alpha$ in ABAP-damaged Caco-2 cells, indicating that the inflammatory symptoms induced by ABAP were effectively alleviated.

\section{Effect of L. plantarum Y44 on Expression of Proteins of the Nrf2 Signaling Pathway in Caco-2 Cells Damaged by ABAP}

The Nrf2 signaling pathway is currently the most studied cell antioxidant pathway. When the Nrf2 signaling pathway is activated, KEAP1 and Nrf2 are in a free state; thus, changes in Nrf2 and KEAP1 expression indicate activation of the Nrf2 signaling pathway. As shown in Figure 5, L. plantarum Y44 increased the expression of Nrf2, KEAP1, and HO-1 in ABAP-damaged Caco-2 cells to a level significantly higher $(P<0.05)$ than that in the ABAP alone and control groups.

Heme oxygenase 1 is a downstream protein of the Nrf2 pathway, and its expression is closely related to Nrf2; HO-1 plays a beneficial role by protecting against oxidative damage and regulating inflammation (Loboda et al., 2016). The activation state of the Nrf2 signaling pathway can be assessed by detecting the expression of HO-1. He et al. (2014) found that Lycium barbarum polysaccharides exerted a protective effect on ischemiareperfusion injury by activating the Nrf2/HO-1 antioxidation pathway. The results above indicated that $L$. plantarum Y44 exerted antioxidant activity by activating the Nrf2/HO-1 pathway in Caco-2 cells.

\section{Effect of L. plantarum Y44 on Expression of Antioxidative-Related Enzymes of Caco-2 Cells Damaged by ABAP}

As shown in Figure 6, the expression of CAT, SOD, and GPX-1 in Caco-2 cells damaged by ABAP was 
(a)

cell

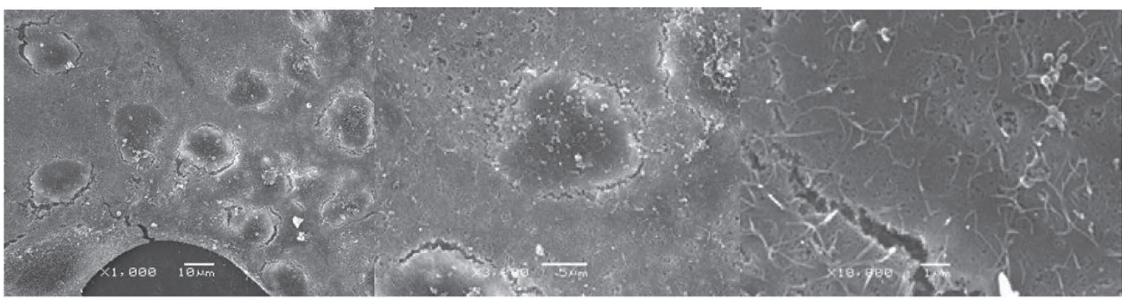

Cell+ABAP

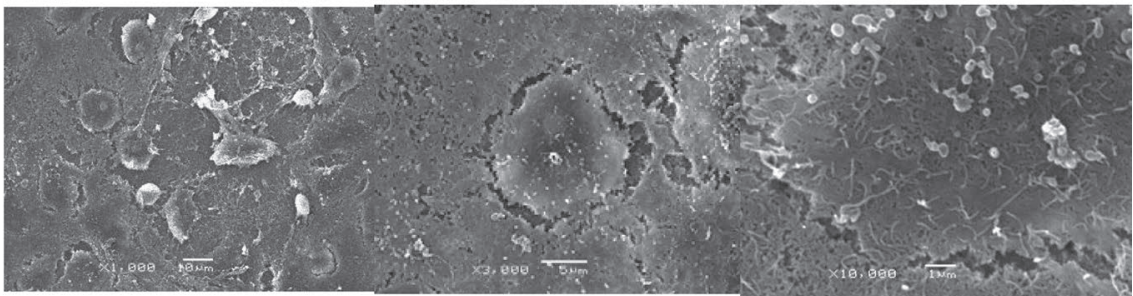

Cell+ABAP+Y44

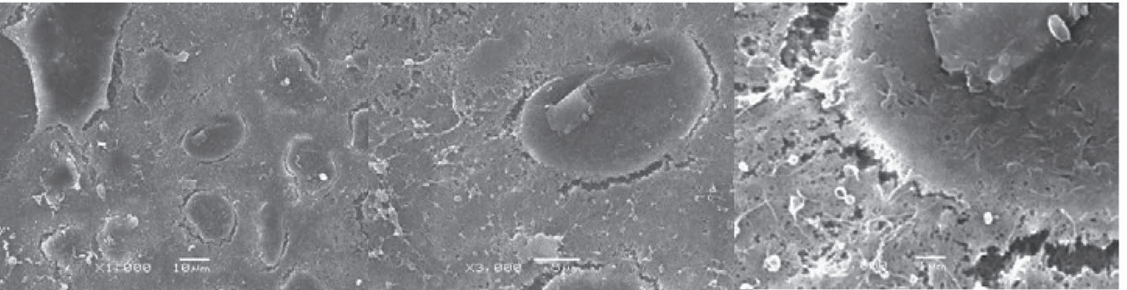

$\times 1,000$

$\times 3,000$

$\times 10,000$

(b)

Control

ABAP

$A B A P+Y 44$

3-Actin

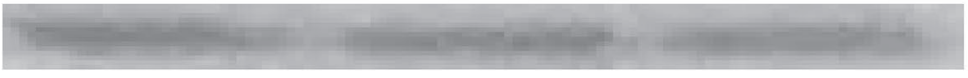

$\beta$-Catenin

(c)

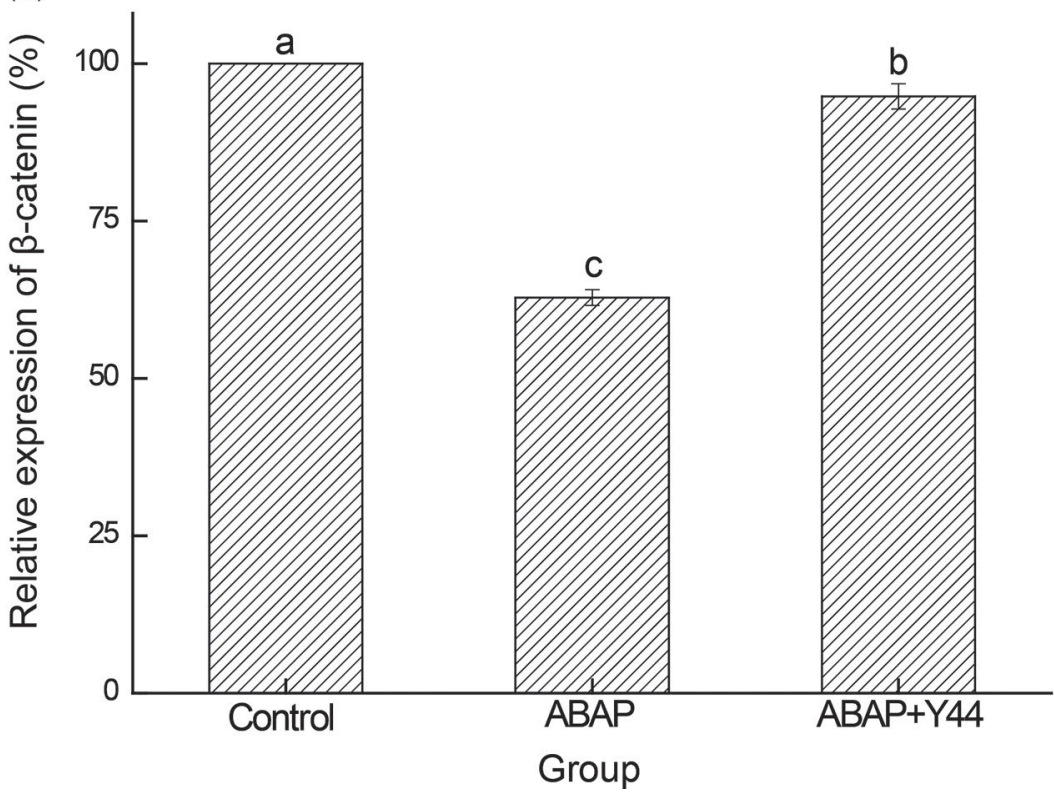

Figure 3. Effect of Lactobacillus plantarum Y44 on the integrity of Caco-2 cells damaged by 2,2'-azobis(2-methylpropionamidine) dihydrochloride (ABAP). (a) Caco-2 cell electron micrographs; (b) Western blot of $\beta$-catenin; (c) relative expression of $\beta$-catenin; (d) Western blot of E-cadherin; and (e) relative expression of E-cadherin. Data shown are means $\pm \mathrm{SD}(\mathrm{n}=3)$. Bars with different letters (a-c) are significantly different $(P<0.05)$. 
significantly enhanced $(P<0.05)$ compared with those of the control group; when Caco-2 cells were treated with L. plantarum Y44 and ABAP, CAT expression was further enhanced $(P<0.05)$, whereas expression of the SOD and GPX-1 did not significantly change $(P>$ $0.05)$ compared with the ABAP group.

Gao et al. (2013) reported that L. plantarum FC225 could stimulate the expression of the Nrf2 antioxidant pathway in mice fed a high-fat diet to elevate the activities of SOD and glutathione peroxidase (GSH-Px). As described above, L. plantarum Y44 activated expression of proteins of the Nrf2 signaling pathway in ABAPdamaged Caco- 2 cells. Thus, the elevated expression of CAT in ABAP-damaged Caco-2 cells treated with $L$. plantarum Y44 might be attributed to activation of the Nrf2 signaling pathway.

\section{DISCUSSION}

Oxidative stress mediated by ROS is related to the development of chronic diseases, including aging, inflammation, cancer, atherosclerosis, cardiovascular disease (Mishra et al., 2015). Some probiotic strains are reported to scavenge ROS and protect the host against ROS injury. In this study, L. plantarum Y44 was found to scavenge oxygen free radicals, protect Caco-2 cells against ABAP damage, maintain Caco-2 cell integrity by enhancing the expression of tight junction proteins, and activate the Nrf2 signaling pathway in ABAP damaged Caco-2cells.

Li et al. (2012) reported that L. plantarum C88 significantly improved the antioxidant status of mice by scavenging ROS and increasing the activity of SOD,

(d)

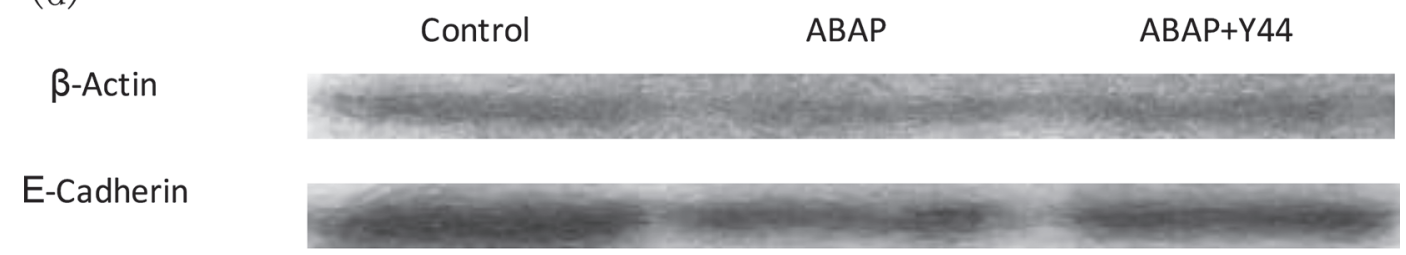

(e)

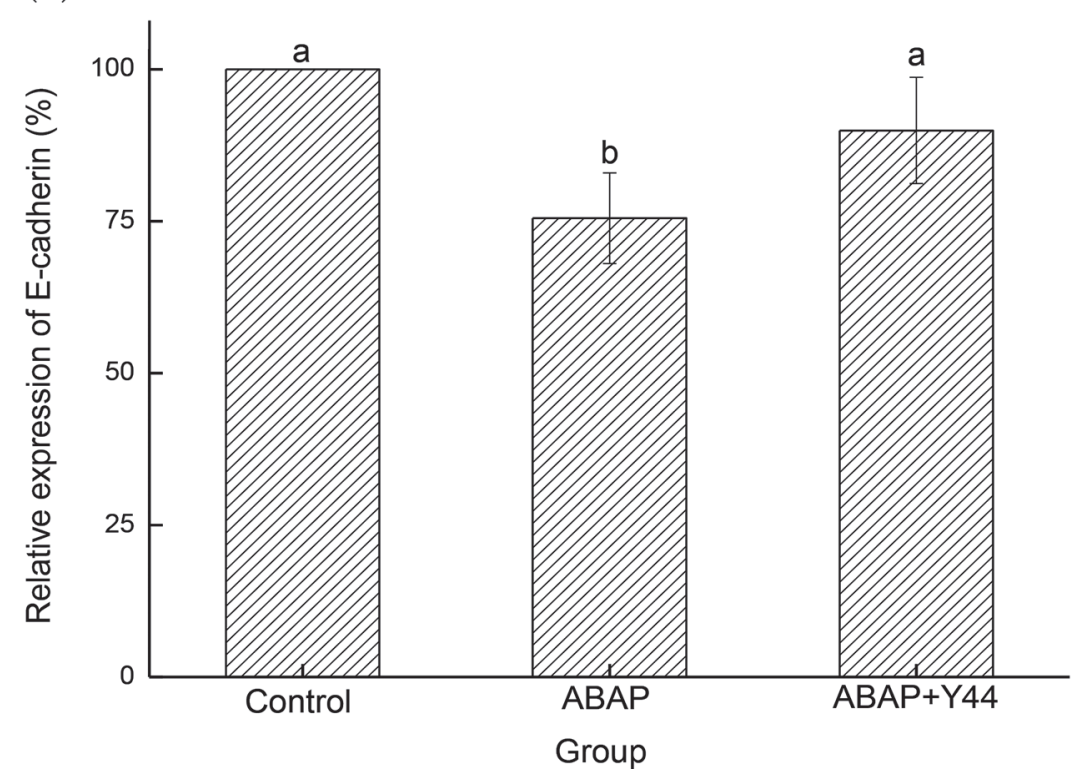

Figure 3 (Continued). Effect of Lactobacillus plantarum Y44 on the integrity of Caco-2 cells damaged by 2,2'-azobis(2-methylpropionamidine) dihydrochloride (ABAP). (a) Caco-2 cell electron micrographs; (b) Western blot of $\beta$-catenin; (c) relative expression of $\beta$-catenin; (d) Western blot of E-cadherin; and (e) relative expression of E-cadherin. Data shown are means $\pm \mathrm{SD}(\mathrm{n}=3)$. Bars with different letters $(\mathrm{a}-\mathrm{c})$ are significantly different $(P<0.05)$. 


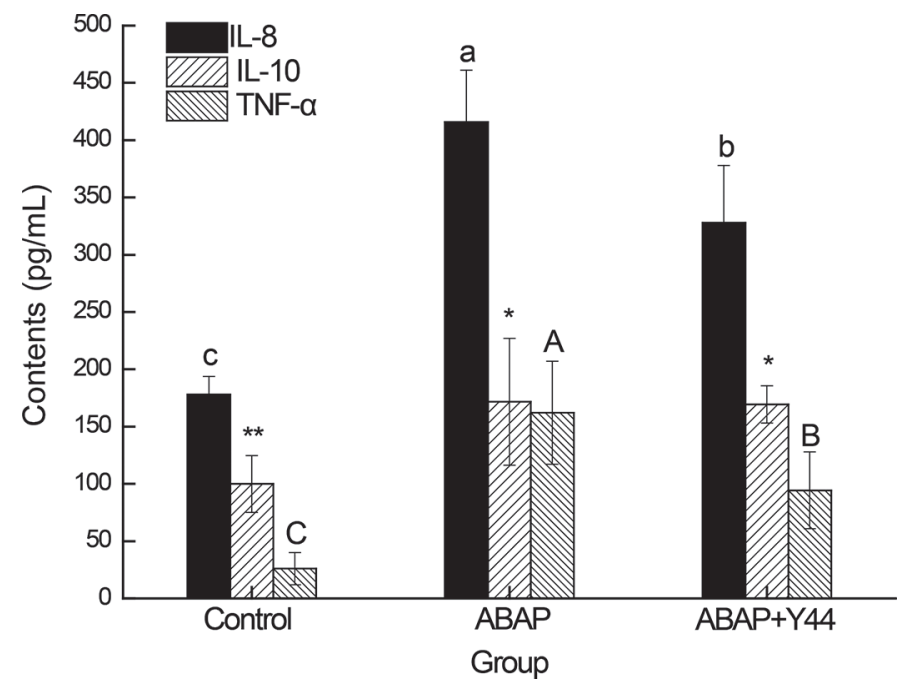

Figure 4. Effect of Lactobacillus plantarum Y44 on expression of IL-8, IL-10, and tumor necrosis factor (TNF)- $\alpha$ of Caco-2 cells damaged by 2,2'-azobis(2-methylpropionamidine) dihydrochloride (ABAP). Data shown are means $\pm \mathrm{SD}(\mathrm{n}=3)$. Different lowercase letters $(\mathrm{a}-\mathrm{c})$ indicate significant differences $(P<0.05)$ in IL-8 content, different uppercase letters $(\mathrm{A}-\mathrm{C})$ indicate significant differences $(P<$ $0.05)$ in IL-10 content, and the number of asterisks indicates significant differences $(P<0.05)$ in TNF- $\alpha$ content. No comparisons were made between IL-8, IL-10, and TNF- $\alpha$.

GSH-Px, and total antioxidant capacity in D-galactoseinduced oxidative stress mice. In this study, the ROS scavenging abilities of L. plantarum Y44 were consistent with the results of cellular antioxidant assays. In these assays, ABAP can generate peroxyl radicals, which damage membranes and other biological molecules in cells (Wolfe and Liu, 2007). Lactobacillus plantarum Y44 might have quenched peroxyl radicals generated by ABAP in Caco-2 cells, and this quenching ability would account for its ability to protect Caco-2 cells from ROS damage.

The Nrf2-ARE antioxidant system is a key endogenous pathway regulating the transcriptional expression of various antioxidant enzymes. Recent studies have shown that activation of Nrf2-ARE protects normal cells and tissues against ROS damage. Furumoto et al. (2016) found that L. plantarum protected hydrogen peroxide-induced HepG2 cells from cytotoxicity by activating the Nrf2 pathway. Huang et al. (2017) reported that $L$. plantarum C88 treatment can attenuate oxidative stress by enhancing the activity of antioxidant enzymes and expression of Nrf2 in mice damaged by aflatoxins. Lin et al. (2018) showed that $L$. plantarum AR501 attenuated the oxidative pressure in D-galactose-induced aging mice by significantly increasing expression of the Nrf2 gene and upregulating expression of several antioxidant enzymes. In this study, expression of Nrf2/KEAP1 pathway-related proteins in Caco-2 cells was enhanced by L. plantarum Y44, as was expression of the antioxidant enzyme CAT.

Excessive ROS can increase the permeability of the intestinal epithelial cells and disrupt barrier function and the integrity of the intestinal epithelial cells. Defective tight junction-related intestinal barriers are a central pathogenic factor in inflammation; the levels of proinflammatory cytokines are increased in inflammatory bowel disease, which increases the permeability of intestinal epithelial tight junctions (Ma et al., 2004). Consumption of probiotics or foods supplemented with probiotics can alleviate the intestinal inflammation caused by ROS and enhance the barrier function of intestinal epithelial cells (Mishra et al., 2015). Celiac disease is associated with increased intestinal epithelial cell permeability and impaired barrier function; Orlando et al. (2018) found that ingestion of L. rhamnosus GG prevented the decrease in expression of intercellular junction proteins that is found in celiac disease, protecting the integrity and function of the intestinal barrier. Han et al. (2019) reported that expression of the tight junction protein 1 (ZO-1) and occludin in intestinal cells of patients with irritable bowel disease were downregulated compared with that of healthy individuals. This downregulation disrupts the homeostasis of intestinal barrier function, whereas pretreatment of intestinal cells with $L$. rhamnosus GG can effectively alleviate these adverse symptoms and protect the integrity of the intestinal barrier. Finamore et al. (2018) showed that L. casei Shirota could prevent membrane barrier disruption and ROS accumulation inside enterocytes through the Nrf2 pathway. In this study, the enhanced expression of tight junction proteins and attenuation of inflammatory cytokines in ABAP-damaged Caco-2 cells pretreated with L. plantarum Y44 might be related to activation of the Nrf2 signaling pathway in Caco-2 cells.

\section{CONCLUSIONS}

We showed that L. plantarum Y44 could scavenge oxygen free radicals, such as DPPH, ABTS, and oxygen free radicals, maintain Caco- 2 cell integrity by enhancing the expression of tight junction proteins $\beta$-catenin and E-cadherin in ABAP-damaged Caco-2 cells, and activate the Nrf2 signaling pathway, as shown by enhanced expression of the proteins Nrf2, KEAP1, and HO-1. Lactobacillus plantarum Y44 may have exerted these antioxidant effects by quenching oxygen free radicals and activating the Nrf2 signaling pathway in Caco2 cells. In vivo animal experiments will be carried out to verify the antioxidant activity of $L$. plantarum Y44. 
(a)

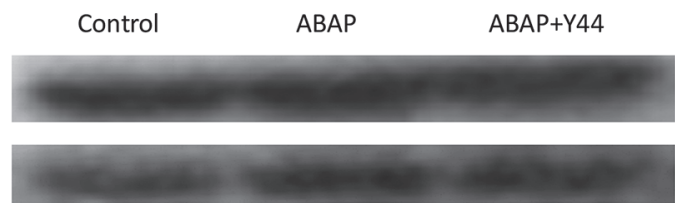

(c)

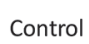

ABAP

$\mathrm{ABAP}+\mathrm{Y} 44$

$\beta$-Actin

Keap1

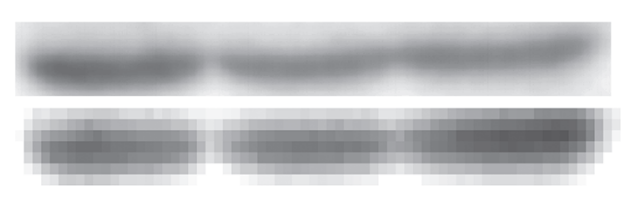

(e)

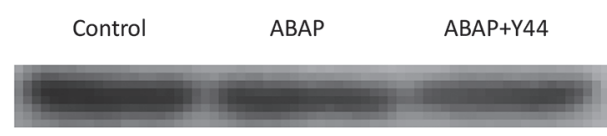

HO-1

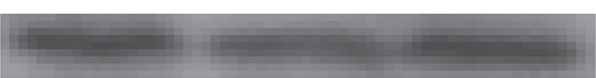

(b)

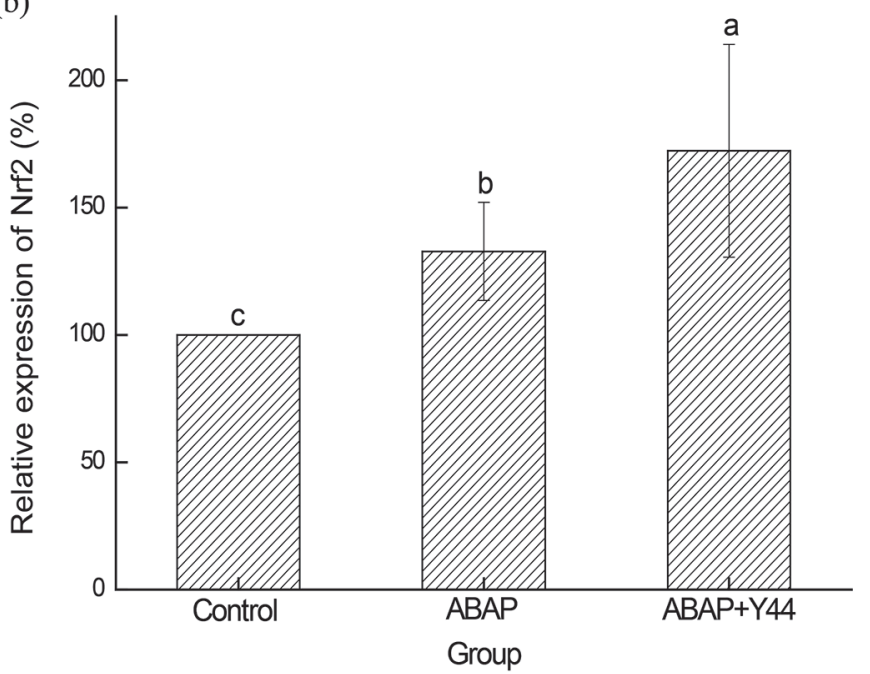

(d)
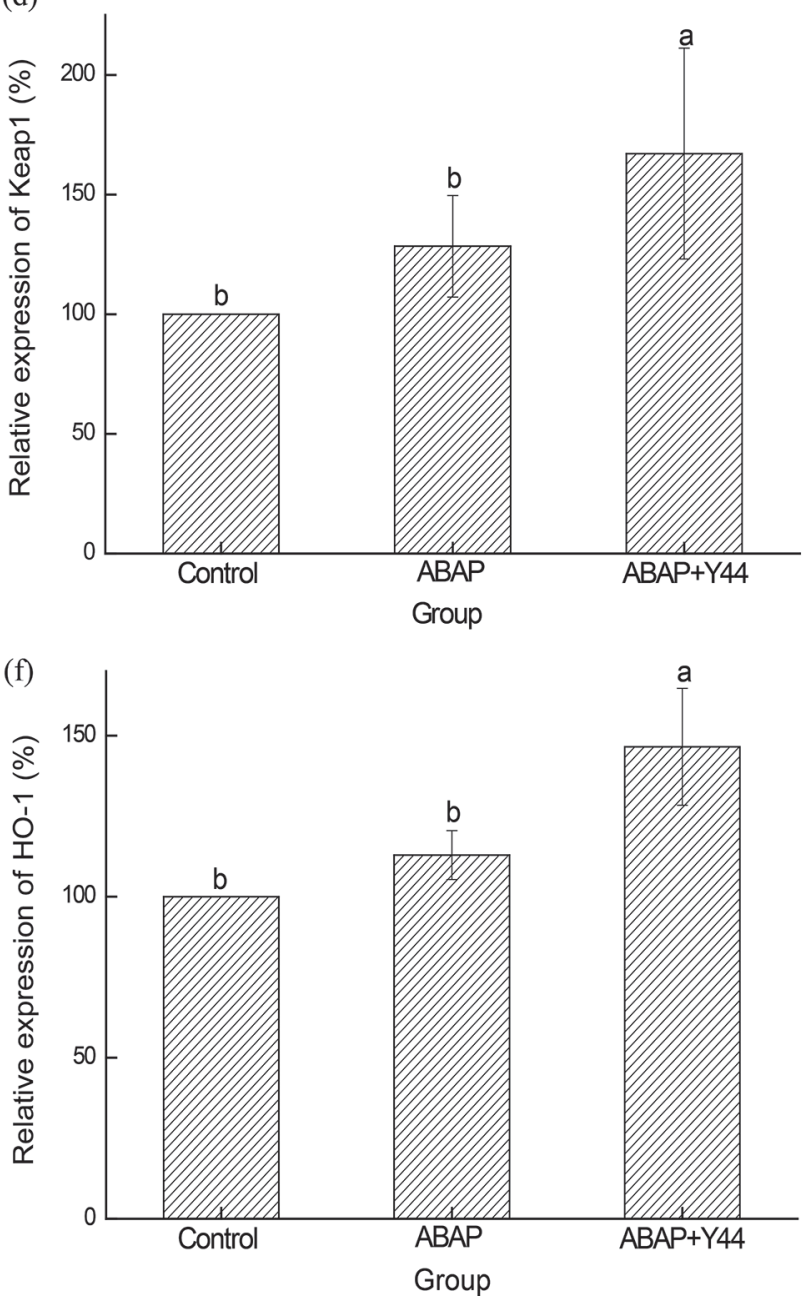

Figure 5. Effect of Lactobacillus plantarum Y44 on the protein expression of nuclear factor-erythroid 2-related factor-2 (Nrf2) signaling pathway in Caco-2 cells damaged by 2,2'-azobis(2-methylpropionamidine) dihydrochloride (ABAP). Western blot (a) and relative expression (b) of Nrf2; Western blot (c) and relative expression (d) of Kelch-like ECH-associated protein 1 (KEAP1); and Western blot (e) and relative expression (f) of heme oxygenase-1 (HO-1). Data shown are means $\pm \mathrm{SD}(\mathrm{n}=3)$. Bars with different letters $(\mathrm{a}-\mathrm{c})$ are significantly different $(P<0.05)$. 
(a)

\section{B-Actin}

Control

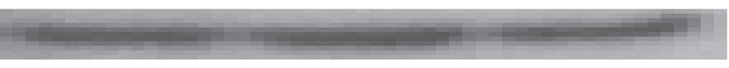

CAT

(c)

$\beta$-Actin

SOD 1

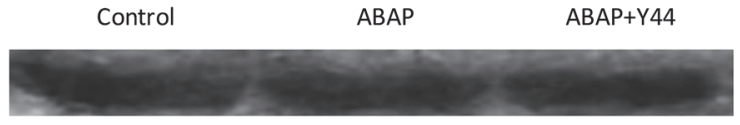

(e)

$\beta$-Actin

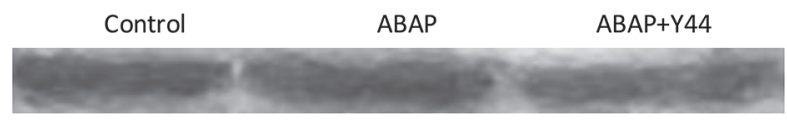

GPX-1
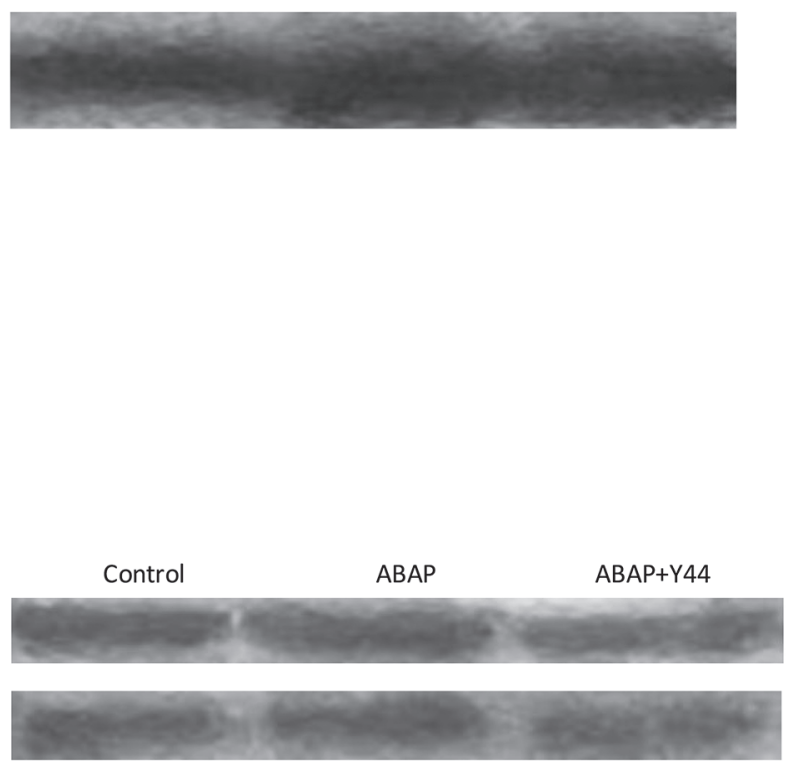

(b)

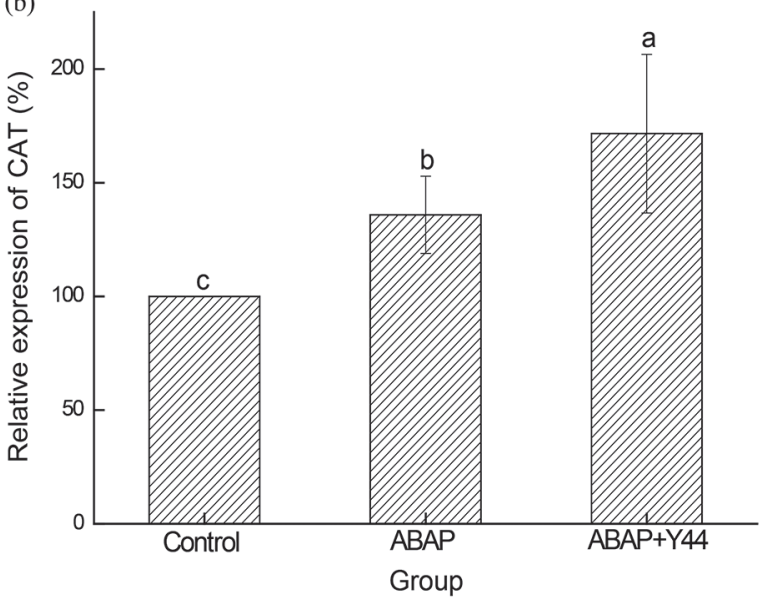

(d)

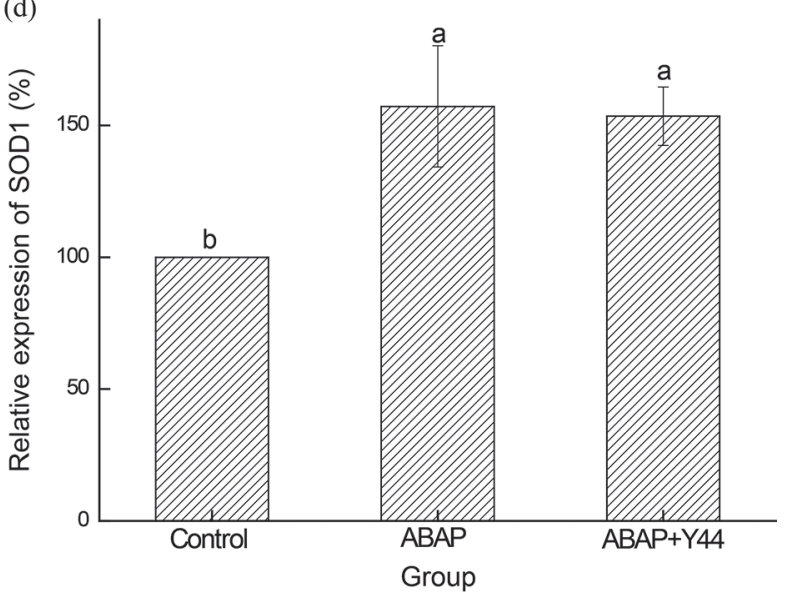

(f)

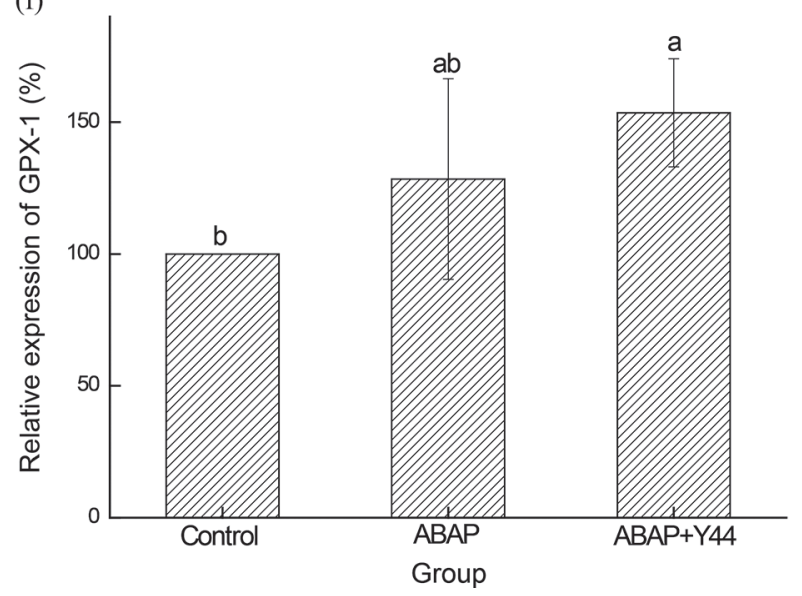

Figure 6. Effect of Lactobacillus plantarum Y44 on the expression of antioxidative-related enzymes of Caco-2 cells damaged by 2,2'-azobis(2methylpropionamidine) dihydrochloride (ABAP). Western blot (a) and relative expression (b) of catalase (CAT); Western blot (c) and relative expression (d) of superoxide dismutase 1 (SOD 1) of superoxide dismutase 1 (SOD 1); and Western blot (e) and relative expression (f) of glutathione peroxidase (GPX-1). Data shown are means $\pm \mathrm{SD}(\mathrm{n}=3)$. Bars with different letters $(\mathrm{a}-\mathrm{c})$ are significantly different $(P<0.05)$. 


\section{ACKNOWLEDGMENTS}

This research project was supported by the National Natural Science Foundation of China (No. 31571813, No. 31671828).

\section{REFERENCES}

Anderson, R. C., A. L. Cookson, W. C. McNabb, Z. Park, M. J. McCann, W. J. Kelly, and N. C. Roy. 2010. Lactobacillus plantarum MB452 enhances the function of the intestinal barrier by increasing the expression levels of genes involved in tight junction formation. BMC Microbiol. 10:316.

Briske-Anderson, M. J., J. W. Finley, and S. M. Newman. 1997. The influence of culture time and passage number on the morphological and physiological development of Caco-2 cells. Proc. Soc. Exp. Biol. Med. 214:248-257.

Chen, P., Q. Zhang, H. Dang, X. Liu, F. Tian, J. Zhao, Y. Chen, H. Zhang, and W. Chen. 2014. Screening for potential new probiotic based on probiotic properties and $\alpha$-glucosidase inhibitory activity. Food Control 35:65-72.

Elisia, I., and D. D. Kitts. 2008. Anthocyanins inhibit peroxyl radicalinduced apoptosis in Caco-2 cells. Mol. Cell. Biochem. 312:139145.

Finamore, A., R. Ambra, F. Nobili, I. Garaguso, A. Raguzzini, and M. Serafini. 2018. Redox role of Lactobacillus casei Shirota against the cellular damage induced by $2,2^{\prime}$-azobis (2-amidinopropane) dihydrochloride-induced oxidative and inflammatory stress in enterocytes-like epithelial cells. Front. Immunol. 9:1131.

Furumoto, H., T. Nanthirudjanar, T. Kume, Y. Izumi, S. B. Park, N. Kitamura, S. Kishino, J. Ogawa, T. Hirata, and T. Sugawara. 2016. 10-Oxo-trans-11-octadecenoic acid generated from linoleic acid by a gut lactic acid bacterium Lactobacillus plantarum is cytoprotective against oxidative stress. Toxicol. Appl. Pharmacol. 296:1-9.

Gao, D., Z. Gao, and G. Zhu. 2013. Antioxidant effects of Lactobacillus plantarum via activation of transcription factor Nrf2. Food Funct. 4:982-989.

Han, X., A. Lee, S. Huang, J. Gao, J. R. Spence, and C. Owyang. 2019. Lactobacillus rhamnosus GG prevents epithelial barrier dysfunction induced by interferon-gamma and fecal supernatants from irritable bowel syndrome patients in human intestinal enteroids and colonoids. Gut Microbes 10:59-76.

He, M., H. Pan, R. C. C. Chang, K. F. So, N. C. Brecha, and M. Pu. 2014. Activation of the Nrf2/HO-1 antioxidant pathway contributes to the protective effects of Lycium barbarum polysaccharides in the rodent retina after ischemia-reperfusion-induced damage. PLoS One 9:e84800.

Huang, L., C. Duan, Y. Zhao, L. Gao, C. Niu, J. Xu, and S. Li. 2017. Reduction of Aflatoxin B1 toxicity by Lactobacillus plantarum C88: A potential probiotic strain isolated from Chinese traditional fermented food "Tofu". PLoS One 12:e0170109.

Li, C., Q. Huang, X. Fu, X. J. Yue, R. H. Liu, and L. J. You. 2015. Characterization, antioxidant and immunomodulatory activities of polysaccharides from Prunella vulgaris Linn. Int. J. Biol. Macromol. 75:298-305.

Li, S., Y. Zhao, L. Zhang, X. Zhang, L. Huang, D. Li, C. Niu, Z. Yang, and Q. Wang. 2012. Antioxidant activity of Lactobacillus plantarum strains isolated from traditional Chinese fermented foods. Food Chem. 135:1914-1919.
Lin, X., Y. Xia, G. Wang, Z. Xiong, H. Zhang, F. Lai, and L. Ai. 2018. Lactobacillus plantarum AR501 alleviates the oxidative stress of D-galactose-induced aging mice liver by upregulation of Nrf2-mediated antioxidant enzyme expression. J. Food Sci. 83:1990-1998.

Loboda, A., M. Damulewicz, E. Pyza, A. Jozkowicz, and J. Dulak. 2016. Role of Nrf2/HO-1 system in development, oxidative stress response and diseases: An evolutionarily conserved mechanism. Cell. Mol. Life Sci. 73:3221-3247.

Ma, T. Y., G. K. Iwamoto, N. T. Hoa, V. Akotia, A. Pedram, M. A. Boivin, and H. M. Said. 2004. TNF- $\alpha$-induced increase in intestinal epithelial tight junction permeability requires NF- $\kappa B$ activation. Am. J. Physiol. Gastrointest. Liver Physiol. 286:G367-G376.

Mishra, V., C. Shah, N. Mokashe, R. Chavan, H. Yadav, and J. Prajapati. 2015. Probiotics as potential antioxidants: A systematic review. J. Agric. Food Chem. 63:3615-3626.

Mu, G., Y. Gao, Y. Tuo, H. Li, Y. Zhang, F. Qian, and S. Jiang. 2018. Assessing and comparing antioxidant activities of lactobacilli strains by using different chemical and cellular antioxidant methods. J. Dairy Sci. 101:10792-10806.

Orlando, A., M. Linsalata, G. Bianco, M. Notarnicola, B. D'Attoma, M. P. Scavo, A. Tafaro, and F. Russo. 2018. Lactobacillus rhamnosus GG protects the epithelial barrier of Wistar rats from the pepsin-trypsin-digested gliadin (PTG)-induced enteropathy. Nutrients 10:1698.

Persichetti, E., A. De Michele, M. Codini, and G. Traina. 2014. Antioxidative capacity of Lactobacillus fermentum LF31 evaluated in vitro by oxygen radical absorbance capacity assay. Nutrition 30:936-938.

Reuter, S., S. C. Gupta, M. M. Chaturvedi, and B. B. Aggarwal. 2010. Oxidative stress, inflammation, and cancer: How are they linked? Free Radic. Biol. Med. 49:1603-1616.

Stinco, C. M., M. V. Baroni, R. D. D. P. Naranjo, D. A. Wunderlin, F. J. Heredia, A. J. Meléndez-Martínez, and I. M. Vicario. 2015. Hydrophilic antioxidant compounds in orange juice from different fruit cultivars: Composition and antioxidant activity evaluated by chemical and cellular based (Saccharomyces cerevisiae) assays. J. Food Compos. Anal. 37:1-10.

Wang, L. X., K. Liu, D. W. Gao, and J. K. Hao. 2013. Protective effects of two Lactobacillus plantarum strains in hyperlipidemic mice. World J. Gastroenterol. 19:3150.

Witaicenis, A., L. N. Seito, A. da Silveira Chagas, L. D. de Almeida Junior, A. C. Luchini, P. Rodrigues-Orsi, S. H. Cestari, and L. C. Di Stasi. 2014. Antioxidant and intestinal anti-inflammatory effects of plant-derived coumarin derivatives. Phytomedicine 21:240-246.

Wolfe, K. L., and R. H. Liu. 2007. Cellular antioxidant activity (CAA) assay for assessing antioxidants, foods, and dietary supplements. J. Agric. Food Chem. 55:8896-8907.

Xing, J., G. Wang, Q. Zhang, X. Liu, Z. Gu, H. Zhang, Y. Q. Chen, and W. Chen. 2015b. Determining antioxidant activities of lactobacilli cell-free supernatants by cellular antioxidant assay: A comparison with traditional methods. PLoS One 10:e0119058.

Xing, J., G. Wang, Z. Gu, X. Liu, Q. Zhang, J. Zhao, H. Zhang, Y. Q. Chen, and W. Chen. 2015a. Cellular model to assess the antioxidant activity of lactobacilli. RSC Adv. 5:37626-37634.

Wang, Y., Y. Wu, Y. Wang, H. Xu, X. Mei, D. Yu, Y. Wang, and W. Li. 2017. Antioxidant properties of probiotic bacteria. Nutrients 9:521

Yokozawa, T., E. J. Cho, Y. Hara, and K. Kitani. 2000. Antioxidative activity of green tea treated with radical initiator $2,2^{\prime}$-azobis $(2$ amidinopropane) dihydrochloride. J. Agric. Food Chem. 48:50685073 . 